\title{
Spring bloom of the raphidophycean Heterosigma akashiwo in the Golden Horn Estuary at the northeast of Sea of Marmara
}

\section{Marmara Denizi'nin kuzeydoğusundaki Haliç̧'te rafidofit Heterosigma akashiwo'nun ilkbahar aşırı çoğalması}

\author{
Fuat Dursun ${ }^{1}$ - Seyfettin Taş ${ }^{*}$ - Tufan Koray² \\ 1 Institute of Marine Sciences and Management, Physical Oceanography and Marine Biology Department, Istanbul University, 34134, Vefa-Fatih, Istanbul- \\ Turkey \\ ${ }^{2}$ Ege University, Faculty of Fisheries, 35100 Bornova, Izmir, Turkey \\ *Corresponding author: stas@istanbul.edu.tr
}

Dursun, F., Taş, S. \& Koray, T. (2016). Spring bloom of the raphidophycean Heterosigma akashiwo in the Golden Horn Estuary at the northeast of Sea of Marmara. Ege Journal of Fisheries and Aquatic Sciences, 33(3): 201-207. doi: 10.12714/egejfas.2016.33.3.03

\begin{abstract}
In the period of February-May 2012, harmful algal blooms (HABs) along with environmental factors were investigated biweekly in the Golden Horn Estuary at the northeast of the Sea of Marmara and a dense bloom of the raphidophyceaen Heterosigma akashiwo (Y.Hada) Y.Hada ex Y.Hara \& M.Chihara was observed in late May. $H$. akashiwo abundance increased gradually from the lower estuary to the upper estuary. The dense bloom of $H$. akashiwo in late May occurred at the temperature of $20.2^{\circ} \mathrm{C}$ and salinity of $16.4 \mathrm{psu}$ and its abundance reached to $10.4 \times 10^{6} \mathrm{cells} \mathrm{L}^{-1}$. When compared to mid-May, the mean temperature of surface water increased $4.50^{\circ} \mathrm{C}$, while salinity decreased $2.30 \mathrm{psu}$ in late May. Secchi depth values decreased rapidly from the lower to the upper estuary $(6.00$ $\mathrm{m}$ to $0.50 \mathrm{~m}$ ). It is considered that a rapid increase in temperature, a decrease in salinity, and high nutrient concentrations in combination with low water circulation at the upper estuary were the causes of the bloom of $H$. akashiwo. Fish mortality or other harmful effects in environment were not observed during the $H$. akashiwo bloom. But, these events may create a potentially toxic risk for the study area in the future.
\end{abstract}

Keywords: Golden Horn Estuary, Harmful algal blooms, Heterosigma akashiwo, nutrients, Sea of Marmara

Öz: Marmara Denizi'nin kuzeydoğusunda bulunan Haliç’te Şubat ve Mayıs 2012 arasındaki dönemde, iki haftada bir olmak üzere çevresel faktörlerle birlikte zararlı alg aşırı üremeleri incelendi ve Mayıs sonunda rafidofit Heterosigma akashiwo (Y.Hada) Y.Hada ex Y. Hara \& M.Chihara türünün yoğun bir aşırı çoğalması gözlendi. $H$. akashiwo bolluğu Haliç'in aşağı bölümünden yukarı bölümüne doğru giderek artmışıı. Mayıs sonundaki $H$. akashiwo'nın yoğun aşıı çoğalması $20.2^{\circ} \mathrm{C}$ sıcaklık ve 16.4 psu tuzlulukta meydana gelmiş ve bolluğu $10.4 \times 10^{6}$ hücre L-1'ye ulaşmıştır. Mayıs ortası ile karşılaştırıldığında Mayıs sonunda ortalama yüzey suyu tuzluluk değerleri $2.30 \mathrm{psu}$, sıcaklık değerleri ise $4.50^{\circ} \mathrm{C}$ artış göstermiştir. Seki derinliği aşağı bölümden yukarı bölüme doğru hızlı bir şekilde azalmıştı $(6.00 \mathrm{~m}$ 'den 0.50 m’ye). Ani bir sıcaklık artışı, tuzlulukta düşüş ve düşük su sirkülasyonu ile birlikte yüksek besin elementleri konsantrasyonu yukarı Haliç'te $H$. akashiwo'nın aşııı çoğalmasının nedenleri olarak düşünülmektedir. $H$. akashiwo aşııı çoğalması boyunca balık ölümü veya ortamda diğer zararlı etkiler gözlenmemiştir. Ancak bu olaylar gelecekte bu çalışma bölgesi için potansiyel toksik bir risk oluşturabilir.

Anahtar kelimeler: Besin elementleri, Haliç, Heterosigma akashiwo, Marmara Denizi, Zararlı alg aşııı üremeleri

\section{INTRODUCTION}

Heterosigma akashiwo (Y.Hada) Y.Hada ex Y.Hara \& M.Chihara (Raphidophyceae) has been known to cause to harmful algal blooms (HABs) and to fish kills around the world (Rensel, 2010). HABs of $H$. akashiwo caused to the large economic losses in British Columbia salmon farms (Haigh and Esenkulova, 2013). In a bloom occurred in Cowichan Bay, Canada, in mid-summer of 2014, high concentrations of $H$. akashiwo (max. $4.00 \times 10^{4}$ cells $\mathrm{mL}^{-1}$ ) caused to lethargic behaviour in salmon species (Esenkulova and Luinenburg,
2014). The harmful effects of $H$. akashiwo blooms on the fish are associated with physical clogging of fish gills by mucus excretion and gill damage by haemolytic substances (Shimada et al. 1983; Chang et al. 1990). Some species and strains of raphidophytes such as Chattonella, Heterosigma and Fibrocapsa may contain brevetoxin-like neurotoxins (Khan et al. 1996; Bridgers et al. 2002, Hallegraeff et al. 2003) and $H$. akashiwo have been considered as the causative organisms of the massive fish mortalities (Mendez et al. 2010). Allelopathic 
effects of $H$. akashiwo are also known for marine invertebrates such as copepods, shrimps and scallops (Keppler et al. 2005; Wang et al. 2006; Yu et al. 2010).

The previous studies on phytoplankton carried out in this study area, when it was extremely polluted, demonstrated that phytoplankton abundance was very low and even they were absent particularly at the upper estuary (Uysal and Unsal, 1996; Tas and Okus, 2003; Tas et al. 2009). During rehabilitation of the GHE (after 2000), phytoplankton abundance increased and dense blooms of phytoplankton occurred in spring and summer (Tas et al. 2009; Tas and Okus, 2011; Tas, 2015). In the previous years, $H$. akashiwo has been recorded in Turkish Seas e.g. in the eutrophic coastal waters of Izmir Bay (Aegean Sea) (Bizsel and Bizsel, 2002; Koray, 2004) and at the near shore of the Sea of Marmara (Deniz and Tas, 2009). The previous study carried out in the Golden Horn Estuary reported summer and autumn blooms of $H$. akashiwo and no harmful effect on the ecosystem caused by this species was recorded (Tas and Yilmaz, 2015).

The main goal of this study is to evaluate a dense bloom of the raphidophycean Heterosigma akashiwo in relation to environmental parameters in the Golden Horn Estuary at the northeast of the Sea of Marmara.

\section{MATERIALS AND METHODS}

\section{Study area}

The Golden Horn Estuary (GHE) is located in southwest of the Strait of Istanbul and is approximately $7.50 \mathrm{~km}$ long and 700 $\mathrm{m}$ wide, with a surface area of $2.60 \mathrm{~km}^{2}$ (Figure 1). The study area is divided in three parts: Lower estuary (LE), middle estuary (ME) and upper estuary (UE). The LE is the deepest section $(40.0 \mathrm{~m})$ and it has a strong interaction with the Strait of Istanbul (Bosphorus). The depth rapidly decreases to $14.0 \mathrm{~m}$ in the ME, where a bridge operating on buoys limits the upper layer circulation. The UE has a depth of $4.00 \mathrm{~m}$ due to a high degree of sedimentation (Figure 1). Although the two streams as known Alibey and Kağıthane carry freshwater to the GHE, the amount of the water runoff is generally low. Therefore, the main source of the freshwater flowing into the GHE is rainfall (Sur et al. 2002). The LE is characterized by a two-layered structure similar to the neighboring Strait of Istanbul where upper layer waters has a salinity of $\sim 18 \mathrm{psu}$, originated from Black Sea and lower layer waters has a salinity of $\sim 38 \mathrm{psu}$, originated from the Mediterranean Sea.

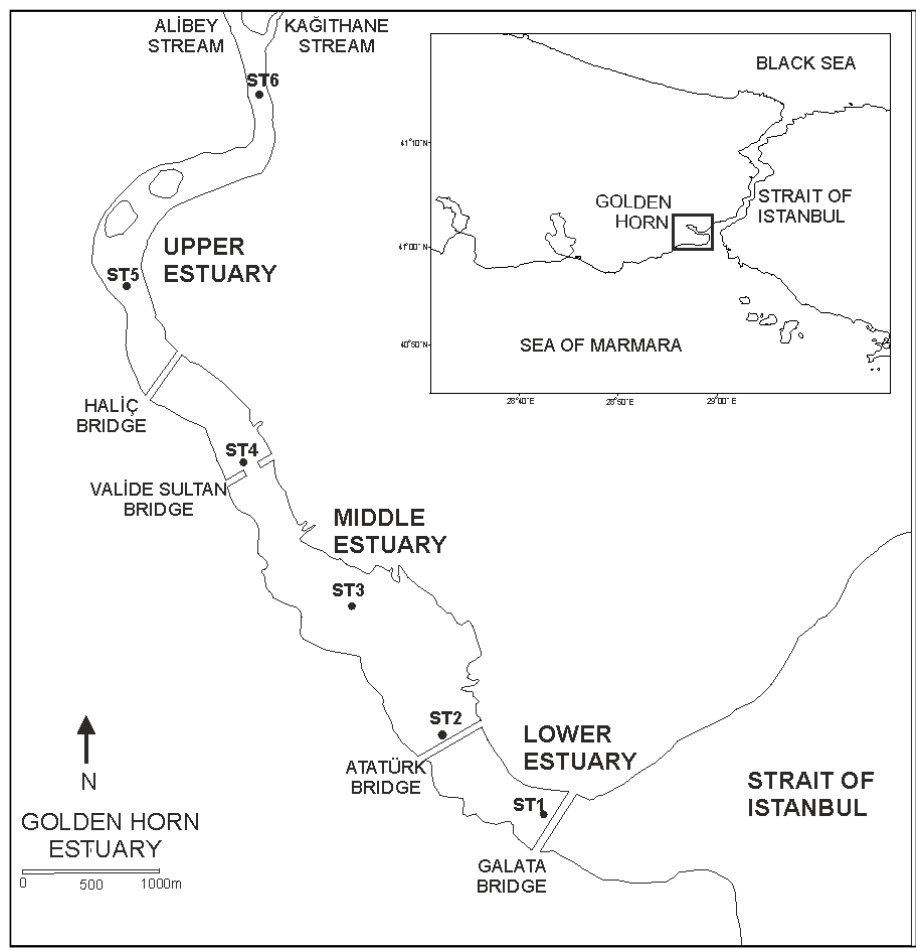

Figure 1. Study area and sampling stations

\section{Sampling and analyses}

Seawater samples were biweekly collected between 21 February and 31 May 2012 in surface water using a Niskin bottle at the six sampling sites. Temperature, salinity, dissolved oxygen (DO) and $\mathrm{pH}$ were measured by a multi-parameter probe (YSI Professional Pro Plus). Light transparency was measured using a Secchi-disc. Inorganic nutrients $\left(\mathrm{NO}_{3}+\mathrm{NO}_{2}\right.$ 
and $\mathrm{PO}_{4}$ ) were analyzed according to methods APHA (1999). Chlorophyll a (Chl-a) analyses were carried out by acetone extraction method according to Parsons et al. (1984). For phytoplankton analyses, $250 \mathrm{~mL}$ seawater was taken by Niskin bottles and preserved with acidic Lugol (2.00\%). $50 \mathrm{~mL}$ subsamples were settled according to Utermöhl Sedimentation Method (Utermöhl, 1958). H. akashiwo cells were counted at 200x magnification under a Leica DM IL LED inverted microscope equipped with phase contrast.

Morphological analyses of $H$. akashiwo cells were carried out using a Leica DM IL LED inverted phase contrast microscope equipped with Image Leica Application Suite software, LAS version 3.8.0 (Leica Microsystems Limited). Taxonomic identification was based on morphological characteristics such as cell shape and size, number, colour and shape of chloroplasts according to Hallegraeff et al. (2003).

\section{RESULTS}

\section{Environmental factors}

The spatial fluctuations in main environmental variables in the three parts (LE, ME and UE) of the GHE are given in Table 1. Relationships between abundance of $H$. akashiwo and environmental variables are presented in Figures 2 and 3.

Table 1. The mean values and standard deviations (SD), minimum and maximum values of environmental factors in surface water of three parts of the GHE during the study period

\begin{tabular}{lcccccc}
\hline & \multicolumn{2}{c}{ LE } & \multicolumn{2}{c}{ ME } & \multicolumn{2}{c}{ UE } \\
\cline { 2 - 7 } Parameters & Mean \pm SD & Min-Max & Mean \pm SD & Min-Max & Mean \pm SD & Min-Max \\
\hline Temperature $\left({ }^{\circ} \mathrm{C}\right)$ & $9.30 \pm 4.91$ & $4.10-16.8$ & $10.6 \pm 5.05$ & $4.50-19.3$ & $11.3 \pm 5.39$ & $5.30-20.7$ \\
Salinity $(\mathrm{psu})$ & $18.9 \pm 0.43$ & $18.4-19.5$ & $17.2 \pm 1.60$ & $15.5-19.1$ & $14.9 \pm 2.32$ & $6.40-19.0$ \\
Secchi depth $(\mathrm{m})$ & $7.20 \pm 1.38$ & $6.00-9.00$ & $2.70 \pm 1.49$ & $1.00-5.00$ & $1.30 \pm 0.64$ & $0.50-3.00$ \\
$\mathrm{NO}_{3}+\mathrm{NO}_{2}-\mathrm{N}(\mu \mathrm{g} \mathrm{L}-1)$ & $5.30 \pm 2.94$ & $1.80-10.3$ & $11.0 \pm 9.50$ & $0.30-25.6$ & $11.9 \pm 8.35$ & $0.10-21.6$ \\
$\mathrm{PO}_{4}-\mathrm{P}\left(\mu \mathrm{g} \mathrm{L}^{-1}\right)$ & $0.60 \pm 0.46$ & $0.30-1.60$ & $1.70 \pm 0.91$ & $0.40-5.20$ & $3.10 \pm 0.99$ & $0.80-11.5$ \\
$\mathrm{Chl}-\mathrm{a}\left(\mu \mathrm{g} \mathrm{L}^{-1}\right)$ & $1.90 \pm 1.19$ & $0.60-3.70$ & $9.70 \pm 31.5$ & $0.50-86.0$ & $8.00 \pm 23.9$ & $0.60-65.9$ \\
$\mathrm{DO}\left(\mathrm{mg} \mathrm{L}^{-1}\right)$ & $10.9 \pm 1.63$ & $9.40-13.4$ & $9.10 \pm 2.36$ & $5.90-11.5$ & $5.20 \pm 2.78$ & $0.20-11.1$ \\
$\mathrm{pH}$ & $7.80 \pm 0.27$ & $7.30-8.10$ & $7.90 \pm 0.17$ & $7.30-8.20$ & $8.00 \pm 0.15$ & $7.70-8.30$ \\
\hline
\end{tabular}

Temperature showed the minor differences between the three parts of the estuary, increasing relatively from the LE to the UE. The mean temperatures in three parts of the GHE for sampling period varied between $9.30^{\circ} \mathrm{C}$ (LE) and $11.3^{\circ} \mathrm{C}$ (UE). But, $H$. akashiwo bloom formed at $20.2^{\circ} \mathrm{C}$. Surface salinity was always lower in the UE and the mean values ranged between
14.9 (UE) and 18.9 psu (LE). But, salinity was 16.4 during the bloom (Figure 2).

Secchi depth decreased significantly from the LE to the UE. The maximum Secchi depth was measured as $9.00 \mathrm{~m}$ at the LE in mid-May, whereas its minimum value was measured as 0.50 $m$ at the UE in late May (Figure 2).

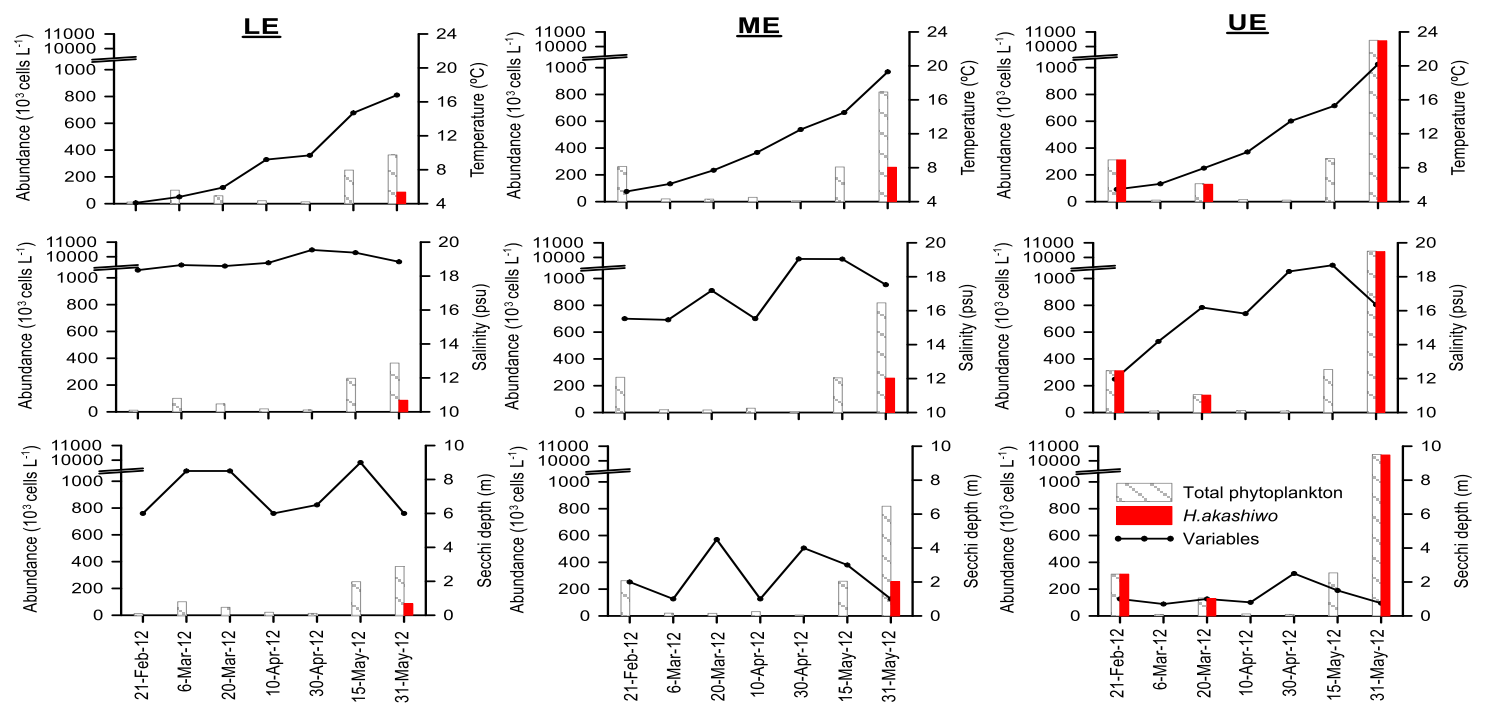

Figure 2. Relationships between $H$. akashiwo abundance and physical factors in the GHE 
Inorganic nutrient concentrations increased remarkably from the LE to the UE due to high amount of nutrient carrying by two streams. While the mean values of $\mathrm{NO}_{3}+\mathrm{NO}_{2}-\mathrm{N}$ varied between $5.30(\mathrm{LE})$ and $11.9 \mu \mathrm{g} \mathrm{L}-1$ (UE), $\mathrm{PO}_{4}-\mathrm{P}$ concentrations ranged between 0.60 (LE) and $3.10 \mu \mathrm{L} \mathrm{L}^{-1}$ (UE) (Figure 3).

Chl-a mean values varied between 1.90 and $8.00 \mu \mathrm{g} \mathrm{L-1}$ from the LE to the UE. The highest chl-a $(86.0 \mu \mathrm{g} \mathrm{L-1})$ was measured in the ME in late May (Figure 3). DO concentrations were often higher at the LE than two other parts of the GHE due to strong interaction with the Strait of Istanbul. The mean DO concentrations changed between 5.30 (UE) and $10.9 \mathrm{mg} \mathrm{L}^{-1}$ (LE) (Figure 3). The highest DO concentration (13.4 $\mathrm{mg} \mathrm{L}^{-1}$ ) was measured in February at the LE, while the lowest $D O$ value $\left(0.2 \mathrm{mg} \mathrm{L}^{-1}\right)$ was measured at the UE in late May (Figure 3). $\mathrm{pH}$ values varied between 7.30 (March, LE) and 8.30 (late May, UE). The mean $\mathrm{pH}$ values were slightly increased (7.80-8.00) from the LE to the UE (Figure 3).

LE

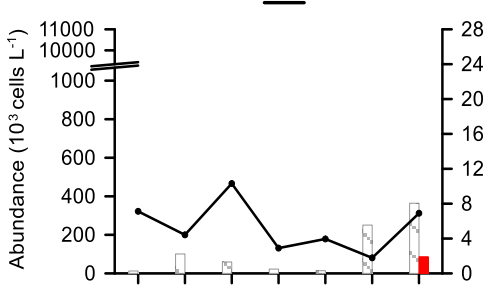

ME

$\underline{\text { UE }}$
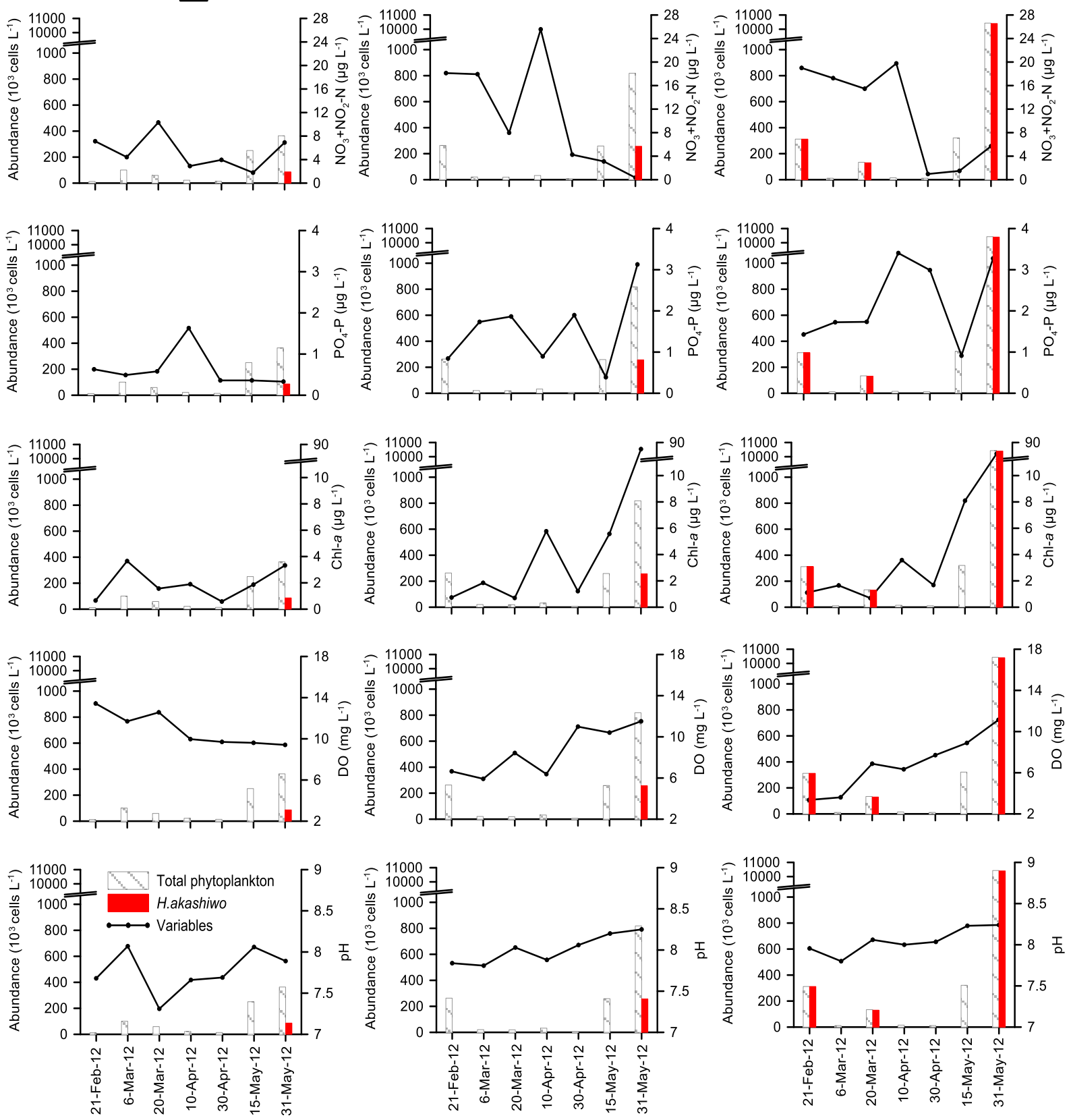

Figure 3. Relationships between $H$. akashiwo abundance and chemical factors in the GHE 


\section{Morphology of $\boldsymbol{H}$. akashiwo cells}

Although cells of $H$. akashiwo were observed as solitary sometimes (Figure 4A), they were observed as masses of immobile spherical cells surrounded by mucilage in some cases (Figure 4B-C). Cell shape varied from ovoid to elliptical, compressing slightly dorso-ventrally, in the length of $8.70-16.20$ $\mu \mathrm{m}$ (average $13.3 \mu \mathrm{m}, \mathrm{n}=20$ ) and in the width of $7.20-13.20 \mu \mathrm{m}$ (average $9.90 \mu \mathrm{m}, \mathrm{n}=20$ ), with two subequal heterodynamic flagella inserted in anterior subapical depression.

Chloroplasts typically varied from yellowish-brown to greenish yellow and the cells contained 8-16 discoid chloroplasts (average 12, $n=20$ ) situated at the cell (Figure $4 C$ ).
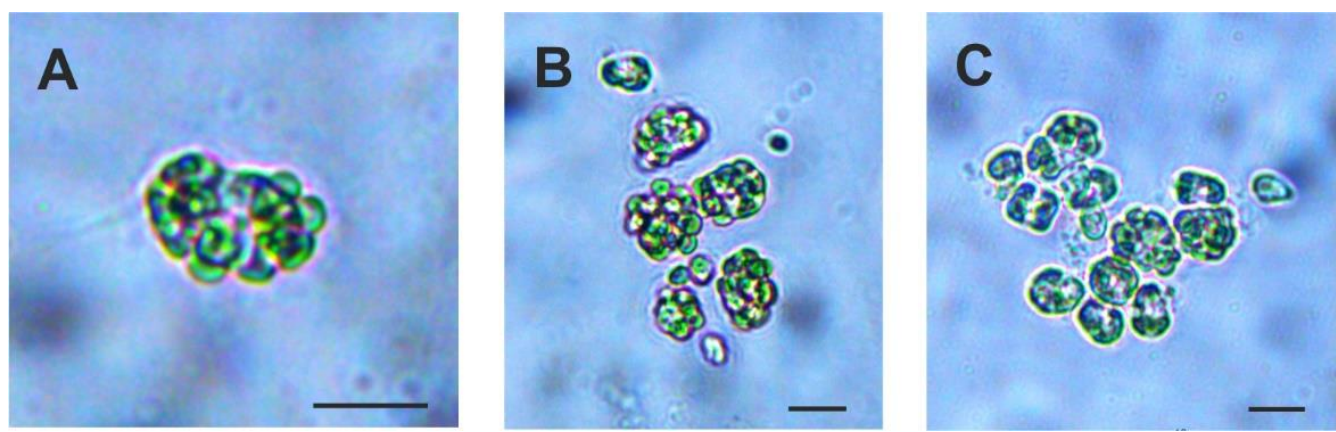

Figure 4. Light micrographs of Heterosigma akashiwo cells in bloom samples in late May in the GHE (A-C). A: Single cell of $H$. akashiwo; B-C: H. akashiwo cells in mucilage colony (Scale bars: $10 \mu \mathrm{m})$

\section{Cell abundance in relation to environmental parameters}

Total phytoplankton abundance including diatoms, dinoflagellates and other flagellates was generally low during the study. However, the abundance began to increase in midMay. While phytoplankton was dominated by diatoms in March, it was dominated by euglenophycean flagellates in early April. It was observed again a diatom increase in late April and this situation lasted in mid-May. Thereafter, $H$. akashiwo formed a dense bloom in late May following the diatom increase in midMay. During the bloom, the contribution of $H$. akashiwo to total phytoplankton increased gradually from the LE to the UE (from $\sim 24 \%$ to $\sim 100 \%$ ). Fluctuations of $H$. akashiwo and total phytoplankton abundance in the study area are shown in Figures 2 and 3.

$H$. akashiwo was firstly found at the UE in February and its cell density was $\sim 0.30 \times 10^{6}$ cells $L^{-1}$. It decreased to $\sim 0.20 \times 10^{6}$ cells $L^{-1}$ in March at the UE. $H$. akashiwo cells were not identified in the LE and ME in these periods. Among April and mid-May, when a diatom increase occurred, $H$. akashiwo cells were not observed throughout the study area. The bloom of $H$. akashiwo occurred at the UE in late May in parallel to a significant temperature rise $\left(\sim 4.50^{\circ} \mathrm{C}\right)$ (Figure 2). $\mathrm{H}$. akashiwo cells were observed at a wide range of water temperatures from 5.30 (February) to $20.2{ }^{\circ} \mathrm{C}$ (late May) and the highest $H$. akashiwo bloom density occurred at $20.2^{\circ} \mathrm{C}$. The relationship between $\mathrm{H}$. akashiwo abundance and temperature levels can be clearly followed in Figure 2. Salinity values were generally lower at the UE than the LE and $H$. akashiwo showed the highest bloom in the UE where salinity values were measured in interval of 14.2 - 16.4 psu in late May. However, in mid-May when the salinity was in $18.7 \mathrm{psu}$ in the UE, there was no bloom caused by $H$. akashiwo in this part of the GHE (Figure 2).

DO concentrations were generally lower in the UE than the other parts of the GHE and they increased to $11.1 \mathrm{mg} \mathrm{L}^{-1}$ during the $H$. akashiwo bloom. The highest chl-a value $\left(\sim 66 \mu \mathrm{g} \mathrm{L}^{-1}\right)$ was recorded in the highest bloom period of $H$. akashiwo. Inorganic nutrient concentrations were higher between February and March than between April and mid-May, probably due to their high uptakes by other phytoplankton groups in middle and late spring periods. However, $\mathrm{NO}_{3}+\mathrm{NO}_{2}-\mathrm{N}$ concentrations rapidly decreased $\left(1.80 \mu \mathrm{g} \mathrm{L}^{-1}\right)$ in the $\mathrm{ME}$ in late May, when diatom abundance was high. But, it was higher $\left(5.70 \mu \mathrm{g} \mathrm{L}^{-1}\right)$ in the UE at the same period. $\mathrm{PO}_{4}-\mathrm{P}$ concentration decreased $\left(0.80 \mu \mathrm{g} \mathrm{L}^{-1}\right)$ in mid-May, but it increased to $3.38 \mu \mathrm{g}$ $\mathrm{L}^{-1}$ in the UE in late May, probably high amount of nutrient input by the streams (Figure 3).

\section{DISCUSSION}

Identification of fixed cells of $H$. akashiwo based on morphological characters under the light microscope is not easy. When preserved with fixatives, their cell membrane shrinks tightly around the cell giving a view similar to a blackberry. Cell morphology, the number and colour of chloroplasts of $H$. akashiwo observed in the GHE were in agreement with the previous descriptions and illustrations in the literature (Tomas, 1997).

Extensive $H$. akashiwo blooms have been observed following the initial spring diatom blooms in the Fraser River (Rensel et al. 2010). Also, in the GHE, the bloom of $H$. akashiwo occurred following a diatom increase as similar to in Fraser River. Moreover, it is known that $H$. akashiwo was reported from 
the eutrophic waters of the Izmir Bay, the Aegean Sea (Bizsel and Bizsel, 2002; Koray, 2004). The first record of Heterosigma cf. akashiwo in the Sea of Marmara was given by Deniz and Tas (2009). As similar to the period of the maximum cell density of $H$. akashiwo in the GHE, Shikata et al. (2008) reported that the maximum cell density of this species $\left(1.20 \times 10^{6}\right.$ cells $\left.L^{-1}\right)$ was at the end of May in the Hakata Bay, Japan. In the previous study carried out in the GHE, there were two blooms of Heterosigma cf. akashiwo in the ME in June and September 2010. The bloom in June $\left(13.9 \times 10^{6}\right.$ cells $\left.L^{-1}\right)$ caused water discoloration and the abundance pattern of the species was highly related to the temperature (Tas and Yilmaz, 2015). In this study, the dense bloom of $H$. akashiwo was observed almost at the same time period (late May) and same part (UE) of the estuary (GHE). Therefore, late May and early June provide the favorable conditions to form dense blooms caused by $H$. akashiwo in the GHE.

Germination of Heterosigma cysts is known to be successful above $15.0{ }^{\circ} \mathrm{C}$ temperature (Rensel, 2007). In the study area, the blooms of $H$. akashiwo occurred following a temperature increase reached to the $15.0^{\circ} \mathrm{C}$ which is the lower limit of the water temperature required for activation of the cysts (Taylor and Haigh, 1993) and the bloom reached to the maximum levels in late May. Kempton et al. (2008) reported the dense bloom of $H$. akashiwo $\left(19.5 \times 10^{6}\right.$ cells $\left.L^{-1}\right)$ in the temperature level of $22.7^{\circ} \mathrm{C}$. In a $\mathrm{H}$. akashiwo bloom $\left(1.20 \times 10^{6}\right.$ cells $\left.\mathrm{L}^{-1}\right)$ occurred in the Hakata Bay of Japan, water temperature was measured over $20.0^{\circ} \mathrm{C}$ (Shikata et al. 2008). Orlova et al. (2010) reported that the dense bloom of $H$. akashiwo $\left(1.00 \times 10^{8}\right.$ cells L-1) occurred in the east coastal area of Vladivostok, Russia at a temperature level of $22.0^{\circ} \mathrm{C}$ in June. In the period of $H$. akashiwo bloom occurred in this study area in June 2010 , water temperature was $21.7^{\circ} \mathrm{C}$ (Tas and Yilmaz, 2015). Both previous studies and this study revealed that there is a significant positive relationship between temperature and bloom formation of $H$. akashiwo, when it was taken into account the temperature rise (from 15.8 to $20.2^{\circ} \mathrm{C}$ ) between middle and late May.

$H$. akashiwo is a euryhaline raphidophycean and can grow at low salinity values under the $10.0 \mathrm{psu}$, but it grows faster at salinities over 10.0 psu (Rensel et al. 2010). Kempton et al. (2008) stated that $H$. akashiwo bloom related to a rapid decrease in salinities (from 31.4 to $21.3 \mathrm{psu}$ ). The water salinity was measured as 16.9 psu during the dense bloom of $H$.

\section{REFERENCES}

American Public Health Association (APHA). (1999). Standard methods for the examination of water and waste water. 20th ed., Washington DC, USA $1325 \mathrm{pp}$.

Bizsel, N. \& Bizsel, K.C. (2002). New records of toxic algae Heterosigma cf akashiwo and Gymnodinium cf. mikimotoi in the hypereutrophic İzmir Bay (Aegean Sea): Coupling between organisms and water quality parameters. Israel Journal of Plant Sciences, 50: 33-44. doi: 10.1560/046H-XV7W-7BQQ-TCTX akashiwo occurred in the GHE in June 2010 (Tas and Yilmaz, 2015). Similar to previous studies, also in the current study, lower salinity values were measured in the upper estuary (UE) in late May compared to middle May. This shows a little negative relationship between salinity and $H$. akashiwo. During this study, the excessive bloom of $H$. akashiwo occurred in the salinity level of 16.4 psu, compatible with the tolerance of this species to low salinities previously reported by various researchers (Branco et al. 2014; Taylor and Haigh, 1993). Salinity levels between 14.0 and 16.0 psu appears to be more appropriate for excessive $H$. akashiwo bloom as shown also in this study area and salinitiy levels higher than 17.0 psu may considerably limit the growth of the $H$. akashiwo. Some authors reported that $H$. akashiwo is a superior competitor at low inorganic nutrient levels (Zhang et al. 2006) and some suggested that it has relatively high inorganic nutrient requirements compared with other flagellates (Smayda, 1998) and $H$. akashiwo bloom occurred together with an increase in DIP and DIN concentrations (Shikata et al. 2008). Nutrient concentrations decreased in mid-May probably due to high diatom uptake, but they increased again in late May probably due to nutrient input by two streams, when $H$. akashiwo bloomed.

The environmental conditions and the ability to form cysts in $\mathrm{H}$. akashiwo play an important role in the population increase and germination of cysts is known to be successful above $15^{\circ} \mathrm{C}$ (Rensel, 2007). A rapid temperature rise $\left(15.7\right.$ to $\left.20.2^{\circ} \mathrm{C}\right)$ in the GHE in late May might be caused to the activation of $H$. akashiwo cysts. Thus, one of the most important factors causing the dense bloom of $\mathrm{H}$. akashiwo is temperature rise. This ability allows to $H$. akashiwo more competitive against other phytoplankton species. Demirel (2015) stated that density and diversity of fish eggs and larvae gradually decrease from the LE towards the UE, due to the deteriorated environmental conditions. No fish mortality was observed caused by Heterosigma akashiwo during the bloom in this study probably due to the scarce of fish assemblages as mentioned above. Although any fish mortality or other harmful effects caused by $H$. akashiwo dense bloom were not observed, these events should be noted for the potential harmful risk in the near future.

\section{ACKNOWLEDGEMENTS}

This study was supported by Scientific Research Projects Coordination Unit of Istanbul University (Grant number: 18585).

Branco, S., Menezes, M., Alves-de-Souz, C., Domingos, P., Schramm, M.A. \& Proenco, L.A.O. (2014). Recurrent blooms of Heterosigma akashiwo (Raphidophyceae) in the Piraquê Channel, Rodrigo de Freitas Lagoon, southeast Brazil. Brazilian Journal of Biology, 74: 529-537. doi: 10.1590/bjb.2014.0074

Bridgers, A., McConell, E., Naar, J., Weidner, A., Tomas, L. \& Tomas, C. (2002). Comparison of regional clones of the genus Chattonella and Fibrocapsa for growth characteristic and potential toxin production. $X^{\text {th }}$ 
International Conference on Harmful Algal Blooms 2002, Florida, USA, pp. 37.

Chang, F,. Anderson, H.C. \& Boustead, N.C. (1990). First record of a Heterosigma (Raphidophyceae) bloom with associated mortality of cagereared salmon in Big Glory Bay, New Zealand. New Zealand Journal of Marine and Freshwater Research, 24: 461-469. doi: 10.1080/00288330.1990.9516437

Demirel, N. (2015). Ichthyoplankton dynamics in a highly urbanized estuary. Marine Biology Research, 11: 677-688. doi: $10.1080 / 17451000.2015 .1007873$

Deniz, N. \& Tas, S. (2009). Seasonal variations in the phytoplankton community in the north-eastern Sea of Marmara and a species list. Journal of Marine Biological Association of the United Kingdom, 89: 269-276. doi: 10.1017/S0025315409003117

Esenkulova, S. \& Luinenburg, O. (2014). Observations of Heterosigma akashiwo bloom and associated wild salmon lethargic behaviour in Cowichan Bay, Canada. Harmful Algae News, 50: 16-18

Haigh, N. \& Esenkulova, S. (2013). Economic losses to British Columbia salmon aquaculture industry due to harmful algal blooms, 2009-2012. PICES Scientific Report, No: 47, pp. 2-6.

Hallegraeff, G.M. (2002). Aquaculturists' guide to harmful Australian Microalgae. $2^{\text {nd }}$ ed. Tasmania, Australia, $135 \mathrm{pp}$.

Hallegraeff, G.M., Anderson, D.M. \& Cembella, A.D. (2003). Manual on harmfu marine microalgae. UNESCO, France, pp. 511-562.

Kempton, J., Kepler, C.J. \& Levitus, A. (2008). A novel Heterosigma akashiwo bloom extending from a South Carolina bay to offshore waters. Harmful Algae, 7: 235-240. doi: 10.1016/j.hal.2007.08.003

Keppler, C.J., Hoguet, J., Smith, K., Ringwood, A.H. \& Lewitus, A.J. (2005) Sublethal effects of the toxic alga Heterosigma akashiwo on the southeastern oyster (Crassostrea virginica). Harmful Algae, 4: 275-285. doi: 10.1016/j.hal.2004.05.002

Khan, S., Arakaw, O. \& Onoue, Y. (1996). Neurotoxin production by a chloromonad Fibrocapsa japonica (Raphidophyceae). Journal of the World Aquaculture Society, 27: 254-263. doi: 10.1111/j.1749-7345.1996.tb00607.x

Koray, T. (2004). Potentially Toxic and Harmful Phytoplankton Species Along the Coast of the Turkish Seas. Harmful Algae, 2002. In: Steidinger, K.A Landsberg, J.H., Tomas, C.R. \& Vargo, G.A. (Eds.), pp. 335-337. Biogeography and regional events sessions. Florida Fish and Wildlife Conservation Commission, Florida Institute of Oceanography, and Intergovernmental Oceanographic Commission of UNESCO.

Mendez, S.M., Akselman, R. \& Tomas, C.R. (2010). First report of Heterosigma akashiwo, Fibrocapsa japonica and Chattonella marina var. antiqua in Uruguay. Proceedings of the 14th International Conference on Harmfu Algae, 1-5 November 2010. Hersonissos, Crete, pp. 123-125

Orlova, T., Morozova, T., Kameneva, P. \& Shevchenko, O. (2010). Harmful algal blooms on the Russian east coast and their possible economic impacts. PICES Scientific Report, No: 47, pp. 41-58.

Parsons T.R., Maita Y. \& Lalli C.M. (1984). A manual of chemical and biological methods for seawater analysis. Oxford, UK: Pergamon Press.

Rensel, J. (2007). Fish kills from the harmful alga Heterosigma akashiwo in Puget Sound: Recent blooms and review. A technical report. National Oceanic and Atmospheric Administration Center for Sponsored Coastal Ocean Research (CSCOR), $58 \mathrm{pp}$

Rensel, J.E., Haigh, N. \& Tynan, T.J. (2010). Fraser river sockeye salmon marine survival decline and harmful blooms of Heterosigma akashiwo. Harmful Algae, 10: 98-115. doi:10.1016/j.hal.2010.07.005
Smayda, T.J. (1998). Ecophysiology and bloom dynamics of Heterosigma akashiwo (Raphidophyceae). Physiological Ecology of Harmful Algal Blooms. In: Anderson, D.M., Cembella, A.D., \& Hallegraeff, G.M. (Eds.) Springer-Verlag, Berlin, Germany, pp. 113-131

Shikata, T., Yoshikawa, S., Matsubara, T., Tanoue, W., Yamasaki, Y. Shimasaki, Y., Matsuyama, Y., Oshima, Y., Jenkinson, I.R. \& Honjo, T. (2008). Growth dynamics of Heterosigma akashiwo (Raphidophyceae) in Hakata Bay, Japan. European Journal of Phycology, 43: 395-411. doi:10.1080/09670260801979295

Shimada, M., Murakami, T.H. \& Imahayashi, T. (1983). Effects of sea bloom, Chattonella antiqua, on gill primary lamellae of the young yellowtail, Seriola quinqueradiata. Acta Histochemica et Cytochemica, 16: 232-244. doi: 10.1267/ahc.16.232

Sur, H.I. Okus, E., Sarıkaya, H.Z., Altıok, H., Eroğlu V. \& Öztürk, I. (2002). Rehabilitation and water quality monitoring in the Golden Horn. Water Science and Technology, 46: 29-36.

Tas, S. \& Okus, E. (2003). The effects of pollution on the distribution of phytoplankton in the surface water of the Golden Horn. Turkish Journal of Marine Sciences, 9: 163-176.

Tas, S., Yilmaz, I.N. \& Okus, E. (2009). Phytoplankton as an indicator of improving water quality in the Golden Horn Estuary. Estuaries and Coasts, 32: 1205-1224. doi: 10.1007/s12237-009-9207-3

Tas, S. \& Okus, E. (2011). A review on the bloom dynamics of a harmful dinoflagellate Prorocentrum minimum (Pavillard) Schiller in the Golden Horn Estuary. Turkish Journal of Fisheries and Aquatic Sciences, 11: 673681. doi: 10.4194/1303-2712-v11 403

Tas, S. (2015). A prolonged red tide of Heterocapsa triquetra (Ehrenberg) $F$. Stein (Dinophyceae) and phytoplankton succession in a eutrophic estuary (Turkey). Mediterranean Marine Science, 16: 621-627. doi: $10.12681 / \mathrm{mms} .1049$

Tas S. \& Yilmaz I.N. (2015). Potentially harmful microalgae and algal blooms in a eutrophic estuary in the Sea of Marmara (Turkey). Mediterranean Marine Science, 16: 432-443. doi: 10.12681/mms.1042

Taylor, F.J.R. \& Haigh, R. (1993). The Ecology of Fish-Killing Blooms of the Chloromonad Flagellate Heterosigma akashiwo in the Strait of Georgia and Adjacent Waters. In: Smayda, T.J., \& Shimizu, Y. (Eds.), pp. 705-771. Toxic Phytoplankton Blooms in the Sea. Elsevier, Amsterdam

Tomas, C.R. (1997). Identifying Marine Phytoplankton. Academic Press: San Diego, USA, 858 pp.

Utermöhl, H. (1958). Zur Vervollkommung der quantitativen PhytoplanktonMethodik. Mitt int Ver Theor Angew Limnologie, 9: 1-38.

Uysal, Z. \& Unsal, M. (1996). Spatial distribution of net diatoms along adjacent of different origin. Turkish Journal of Botany, 20: 519-527.

Wang, L., Yan, T. \& Zhou, M. (2006). Impacts of HAB species Heterosigma akashiwo on early development of the scallop Argopecten irradians Lamarck. Aquaculture, 255(1-4): 374-383 doi: 10.1016/j.aquaculture.2005.11.057

Yu, J., Yang, G. \& Tian, J. (2010). The effects of the harmful alga Heterosigma akashiwo on cultures of Schmackeria inopinus (Copepoda, Calanoida). Journal of Sea Research, 64: 287-294. doi: 10.1016/j.seares.2010.04.002

Zhang, Y., Fu, F.X., Whereat, E., Coyne, K.J. \& Hutchins, D.A. (2006). Bottomup controls on a mixed-species $\mathrm{HAB}$ assemblage: A comparison of sympatric Chattonella subsalsa and Heterosigma akashiwo (Raphidophyceae) isolates from the Delaware Inland Bays, USA. Harmful Algae, 5: 310-320. doi: 10.1016/j.hal.2005.09.001 